\title{
Znaczenie ruchu w edukacji matematycznej Ucieleśnione poznanie a kształtowanie się umysłowych reprezentacji liczb u dzieci
}

\begin{abstract}
The importance of motor activity in mathematics education. Embodied cognition and development of mental representation of numbers in children This paper presents the review of literature concerning the importance of relationship between motor and cognitive activity in mathematical skills development. Cognitive and motor processing seem not to be related as well as the use of motor activity in the processing of numbers is far from an intuitive approach in mathematical education. A great number of studies show, however, that cognitive processes are embodied and therefore the involvement of movement in tasks requiring the participation of cognitive processes gives extremely positive results. This applies to both mathematics education practice in the case of children with normal development and those with a cognitive deficit in this area, called developmental dyscalculia. It is not surprising, therefore, the growing popularity of modern technologies that involve movement, which are used for cognitive math skills training, such as motion sensors, dance mats or educational games with elements of movement and dance. The beneficial influence of motor activity in mathematical abilities development is related to the spatial organization of representations of numbers arranged on the so-called Mental Number Line. It has been confirmed that such motor training develops and strengthens this spatial-numerical association, which is a predictor of skills of children in arithmetic.
\end{abstract}

Key words: mathematics education, modern technologies, cognitive-motor trainings, embodied cognition 


\section{Wprowadzenie}

Czynności poznawcze i ruchowe z pozoru mogą nie mieć ze sobą nic wspólnego, zaś wykorzystanie ruchu w nauce matematyki czy - generalnie - w przetwarzaniu liczb, być dalekie od intuicyjnego podejścia w edukacji matematycznej. Liczne badania pokazują jednak, że procesy poznawcze są ucieleśnione i z tego powodu zaangażowanie ruchu w zadaniach wymagających udziału procesów poznawczych daje niezwykle pozytywne rezultaty. Dotyczy to zarówno nauki matematyki w przypadku dzieci prawidłowo rozwijających się, jak i tych, u których obserwuje się deficyt $\mathrm{w}$ tym zakresie nazywany dyskalkulią. Nie dziwi więc rosnąca popularność nowoczesnych technologii angażujących ruch, stosowanych $\mathrm{w}$ treningach poznawczych umiejętności matematycznych, takich jak czujniki ruchu, maty taneczne czy po prostu edukacyjne zabawy z elementami ruchu i tańca. Korzystny wpływ ruchu jest związany $z$ istnieniem przestrzennych reprezentacji liczb rozmieszczonych na tzw. mentalnej osi liczbowej, którą takie treningi ruchowe kształtują i utrwalają, a to z kolei przekłada się na umiejętności dzieci $\mathrm{w}$ arytmetyce.

\section{Dualizm kartezjański ciała i umysłu a ucieleśnienie poznania}

Jedno z pytań, na które nauka usiłuje znaleźć odpowiedź, to „Jak (i czy) niefizyczny i nieprzestrzenny umysł może oddziaływać z fizycznym i przestrzennym ciałem i za jego pośrednictwem wpływać na świat fizyczny?”. Wciąż nie wypracowano jednoznacznego rozwiązania tego problemu. Przyjmuje się, że początek rozważań nad relacją umysł-ciało dał Rene Descartes (Kartezjusz), a jego stanowisko znajduje się w opozycji do koncepcji umysłu ucieleśnionego, zgodnie z którą procesy poznawcze są głęboko zakorzenione $w$ interakcjach cielesnych ze światem ${ }^{1}$. Zatem czy odrzucenie proponowanego przez Kartezjusza dualizmu implikuje uznanie poglądu, że umysł jest ucieleśniony? Jakie przesłanki przemawiają na rzecz paradygmatu umysłu ucieleśnionego?

\section{Koncepcja Kartezjusza}

Kartezjusz jest uznawany za tego, który oddzielił umysł od ciała. Wyróżnił dwie substancje, z których złożony jest człowiek - res cogitas (rzecz myśląca; innymi słowy: umysł) i res extensa (rzecz rozciągła, czyli ciało). W swoich rozważaniach doszedł do wniosku, że istnienie jest pochodną myślenia, byt został sprowadzony

1 M. Wilson, Six views of embodied cognition, „Psychonomic Bulletin\&Review” 2002, t. 9, nr 4, s. 625-636. 
do samoświadomości i jest uprawomocnieniem istnienia podmiotu. Nie potrafił jednak wykazać, że świat rzeczywiście istnieje, bowiem to, co myślimy, dane jest za pośrednictwem zmysłów, a te niekiedy wprowadzają nas w błąd. Nie był więc pewny istnienia rzeczy zewnętrznych, bo są one dane za pośrednictwem zmysłów, jednakże był przekonany o istnieniu własnej myśli. Zatem jeśli jest myśl i „myślę, więc jestem”, to musi istnieć „coś”, co myśli, co jest niezależną substancją i istnieje, choćby wszystko inne było złudzeniem. Jest tym jaźń (umysł) niezależna od ciała. Tym samym Kartezjusz wskazał, że wiedzy pewnej, fundamentalnej należy szukać w podmiocie, bowiem świat myśli jest bardziej wiarygodny niż cokolwiek inne$\mathrm{go}^{2}$. Krytyka poznania zmysłowego doprowadziła więc do oddzielenia rzeczywistości od doświadczeń poznawczych, a w konsekwencji do dualizmu umysłu i ciała (zmysłów) .

\section{Oblicza ucieleśnienia umysłu}

W opozycji do dualizmu sformułowano teorię umysłu ucieleśnionego, która wyrasta na gruncie fenomenologii, lingwistyki i neuronauk. Powstała ona w odpowiedzi na obliczeniową teorię umysłu, która zakłada, że umysł jest programem dokonującym obliczeń na symbolach w oparciu o algorytmy i reguły ${ }^{4}$. Teoria umysłu ucieleśnionego zakłada, że system poznawczy człowieka jest rozszerzony na inne części ciała i poza nie wykracza - składa się z mózgu, ciała i środowiska.

Fenomenologia jako jedna z pierwszych wskazała na cielesny i aktywny charakter percepcji ${ }^{5}$. Pierwsze wzmianki o cielesności poznania znaleźć można u twórcy fenomenologii, Husserla ${ }^{6}$. Uważał on, że ciało ma istotny wpływ na proces poznania alter ego i kształtowanie (konstytucję) świata intersubiektywnego. Zmysł dotyku jest najważniejszym zmysłem, a w połączeniu z ruchem jest kluczowy dla konstytuowania otaczającej przestrzeni oraz postrzegania rzeczy materialnych. Jednym z najważniejszych założeń jego koncepcji ciała jest uzależnienie percepcji od cielesnej motoryki. Ciało stanowi zatem punkt odniesienia dla kierunków (góra-dół, lewo-prawo), relacji (blisko-daleko) oraz kategorii (tu-tam). Następnie Ponty zaproponował pogląd, że człowiek jest cielesnością, nie czystą

${ }^{2}$ W. Tatarkiewicz, Historia filozofii, t. II, Filozofia nowożytna do roku 1830, Warszawa 2018.

${ }^{3}$ H. Kiereś, Filozofia współczesna, [w:] U źródeł tożsamości kultury europejskiej, red. T. Rakowski, Lublin 1994, s. 219-232.

${ }^{4}$ B. Trybulec, Fenomenologia a kognitywistyka - dwie metody analizy podmiotu poznania. Perspektywa współpracy i problemy, „Filozofia i nauka. Studia filozoficzne i interdyscyplinarne” 2015, t. 3, s. 281-299.

${ }_{5}^{5}$ M. Pokropski, Ciało. Od fenomenologii do kognitywistyki, „Przegląd Filozoficzno-Literacki” 2011, nr 4 (32), s. 119-137.

6 Tamże. 
świadomością, a $\mathrm{z}$ interakcji cielesnego podmiotu $\mathrm{z}$ otoczeniem wyłania się proces rozumienia/zachowania, zaś ciało jest jego narzędziem. Zatem motoryka i percepcja są od siebie zależne - ruch wpływa na postrzeganie, a ono z kolei jest bodźcem do zmiany położenia ciała. Ponty uważa też, że ciało jest w stanie wytworzyć jedność z używanymi przedmiotami ${ }^{7}$.

Podobnie za kluczowe uznaje się założenie lingwistyki kognitywnej, że znaczenie jest formowane przez zjawisko ucieleśnienia poznania. Oznacza to, że budowa ciała, jego umiejscowienie w świecie i świadomość cech anatomicznych ciała (możliwości i ograniczeń) wywierają wpływ na kształtowanie się znaczeń. To umożliwia powstawanie tzw. schematów wyobrażeniowych. Lakoff i Johnson ${ }^{8}$ są zwolennikami poglądu, że pojęcia, których bezpośrednio nie doświadczamy, muszą bazować na metaforze lub metonimii, ponieważ łatwiej jest dokonać ich opisu poprzez odwołanie się do codziennych doświadczeń czy interakcji z przedmiotami fizycznymi, których cechy możemy spostrzegać i tworzyć z nimi skojarzenia.

Neuronauka to kolejny obszar, w którym można zaobserwować silną korelację między ucieleśnieniem a funkcjonowaniem poznawczym i motorycznym. Warto zwrócić uwagę na zagadnienie schematu i obrazu ciała, służące do opisu zjawisk zachodzących poza poznawczą reprezentacjąa . Obraz ciała odnosi się do jego percepcji, a także postaw i przekonań z nim związanych - jest to personalne doświadczanie siebie, przeświadczenie, że ciało jest moje. Natomiast schemat ciała to nieświadoma jego mapa, dzięki której możliwe jest programowanie i monitorowanie ruchów jego części. Odpowiada za postawę i ruch ciała, co odbywa się w znacznym stopniu na poziomie automatycznym. W przypadku ruchów intencjonalnych są one skoordynowane dzięki istnieniu i funkcjonowaniu schematu ciała podporządkowanemu celowi ruchu. Schemat ciała mieści w sobie trzy jego aspekty: propriocepcję (przetwarzanie informacji dotyczących ruchu i postawy), nawyki i programy motoryczne (wrodzone i wyuczone) oraz zdolności, które umożliwiają komunikację między zmysłami a propriocepcją (co pozwala np. na powtórzenie widzianego ruchu $)^{10}$. Ze względu na ucieleśnienie, spostrzeganie jest egocentryczne, bowiem percypujemy coś z określonej perspektywy. Co więcej, na spostrzeganie wpływają emocje, które mają swoje źródło w odczuciach cielesnych (stanowią tło i kształtują możliwości, ramy działania). Inną interesującą kwestią w tym kontekście są wyniki badań dotyczących neuronów lustrzanych, które wskazują na

\footnotetext{
7 Tamże.

${ }^{8}$ D. Gonigroszek, Językoznawstwo kognitywne: „ucieleśniony” umysł i znaczenie, „Językoznawstwo" 2011, nr 5(1), s. 13-20.

9 J. Trzópek, Na tropach podmiotu. Między filozoficznym a empirycznym ujęciem podmiotowości, Kraków 2013.

10 Tamże.
} 
istnienie związku między tym, co widzimy, a tym, czego doświadczamy we własnym ciele ${ }^{11}$. Obserwacja działania wywołuje symulację wykonania takiej samej czynności. Zatem dochodzi do aktywacji niektórych neuronów kory przedruchowej zarówno podczas obserwowania, jak i wykonywania czynności. To wskazuje na istnienie bezpośredniego połączenia między systemem motorycznym i sensorycznym. $Z$ ucieleśnieniem poznania koresponduje też fakt, że możliwości poznawcze u dzieci i zwierząt mają związek z ich ruchliwością i eksploracją ${ }^{12}$. Wobec tego ciało jest kluczowym czynnikiem kształtującym percepcję.

\section{Kompetencje matematyczne}

Prawidłowy rozwój kompetencji matematycznych jest niezwykle ważny dla efektywnego codziennego funkcjonowania, zwłaszcza w obliczu rosnącej roli technologii we współczesnym świecie. Niski poziom umiejętności matematycznych ma negatywny wpływ na przebieg edukacji jednostek, perspektywy ich zatrudnienia i zdrowie psychiczne. To zaś przekłada się bezpośrednio na status ekonomiczny $\mathrm{kraju}^{13}$.

\section{Kształtowanie umiejętności matematycznych}

Nie rodzimy się z w pełni wykształconymi umiejętnościami matematycznymi. Jest to raczej efekt długotrwałego procesu rozwoju umysłowych reprezentacji liczb i tzw. zmysłu numerycznego ${ }^{14}$. Czynniki biologiczne stanowią podstawę tych zdolności, jednakże niezbędny jest także wpływ procesu uczenia się i czynników środowiskowych. Kształtowanie się mentalnych reprezentacji liczb jest zorganizowane hierarchicznie ${ }^{15}$. Jakie są zatem stadia rozwoju umiejętności matematycznych i jakie jest ich mózgowe podłoże?

${ }^{11}$ G. Rizzolatti, L. Fogassi, V. Gallese, Mirrors In The Mind, „Scientific American” 2006, s. 54-61.

12 E. Reikerås, T. Moser, F.E. Tønnessen, Mathematical skills and motor life skills in toddlers: do differences in mathematical skills reflect differences in motor skills?, „European Early Childhood Education Research Journal" 2015, t. 25, nr 1, s. 1-17; R. Held, A. Hein, Movement-produced stimulation in the development of visually guided behavior, „Journal of Comparative and Physiological Psychology" 1963, t. 56, nr 5, s. 872-876; J. Trzópek, dz. cyt.

${ }^{13}$ K. Kucian, M. von Aster, Developmental dyscalculia, „Eur J Pediatr” 2015, t. 174, nr 1, s. 1-13.

${ }_{14}$ S. Dehaene, Number sense. How the mind creates mathematics, United States of America 1997.

15 M.G. von Aster, R.S. Shalev, Number development and developmental dyscalculia, „Developmental Medicine \& Child Neurology" 2007, t. 49, nr 11, s. 868-873. 


\section{Okres niemowlęcy}

Przejawy umiejętności matematycznych w tym okresie niewątpliwie świadczą o pewnych biologicznych, wrodzonych mechanizmach, które je warunkują ${ }^{16}$. $\mathrm{Na}$ tym etapie obserwuje się istnienie analogowej reprezentacji liczb w umyśle. Jej obecność przejawia się na przykład zdolnością odróżniania liczebności zbiorów dzięki szybkiemu określaniu niewielkiej liczby elementów (tzw. subitacja, ang. subitizing) czy szacowania. Struktury kluczowe dla wykształcenia się reprezentacji analogowej znajdują się w płatach ciemieniowych obu półkul ${ }^{17}$. Wykształcenie takiej umysłowej reprezentacji liczb jest warunkiem koniecznym do nabycia kolejnych - werbalnej (operowanie liczebnikami) i symbolicznej (operowanie cyframi arabskimi). Umożliwia to późniejsze zrozumienie związku postrzeganej liczby obiektów z jej reprezentacją słowną i symboliczną.

\section{Okres wczesnoszkolny}

Kolejną kształtującą się w dzieciństwie reprezentacją liczb jest wspomniana już reprezentacja werbalna ${ }^{18}$. Przeliczanie jest ogniwem łączącym wrodzone zdolności matematyczne z bardziej zaawansowanymi umiejętnościami ${ }^{19}$. Opanowanie tej umiejętności przez dziecko trwa około czterech lat i ma początek około drugiego roku życia. To wtedy dzieci zaczynają używać pierwszych liczebników i rozumieć zasadę jeden do jednego (niezależnie od znajomości sekwencji liczebników). Co więcej, większość dzieci 3,5-letnich potrafi uchwycić pojęcie liczebności małych zbiorów obiektów oraz wie, że przeliczanie jest sposobem na ustalenie liczebności zbioru (zasada kardynalności). Dzieci 4-letnie często posiłkują się palcami przy wykonywaniu prostych obliczeń. Sprawnie transferują reprezentację analogową na werbalną i odwrotnie. Około piątego roku życia potrafią natomiast poprawnie wykonywać operacje dodawania bez konieczności przeliczania niewielkich zbiorów ${ }^{20}$. Reasumując, rozwój werbalnej reprezentacji liczb jest podłożem umiejętności słownego odliczania, rozwinięcia poznawczych strategii liczenia

16 Tamże; K. Patro, H.C. Nuerk, U. Cress, M. Haman, How number-space relationships are assessed before formal schooling: A taxonomy proposal, „Frontiers in Psychology” 2014, t. 5, nr 419; M.D. de Hevia, E.S. Spelke, Number-space mapping in human infants, „Psychological Science” 2010, t. 21, s. 653-660.

17 M.G. von Aster, R.S. Shalev, dz. cyt.; E.M. Hubbard, M. Piazza, P. Pinel, S. Dehaene, Interactions between number and space in parietal cortex, „Nature Review Neuroscience” 2005, t. 6, s. 435-448; S. Dehaene, N. Molko, L. Cohen, A.J. Wilson, Arithmetic and the brain, „Current Opinion in Neurobiology" 2004, t. 14, nr 2, s. 218-224.

${ }_{18}$ M.G. von Aster, R.S. Shalev, dz. cyt.

19 B. Butterworth, The development of arithmetical abilities, „Journal of Child Psychology and Psychiatry" 2005, t. 46, nr 1, s. 3-18.

20 Tamże. 
oraz zapamiętywania i wydobywania prostych faktów arytmetycznych. Neuronalną bazą tych zdolności są struktury czołowe lewej półkuli²1 .

\section{Okres szkolny}

W okresie szkolnym u dzieci kształtuje się wzrokowo-symboliczna reprezentacja liczb ${ }^{22}$ dzięki operowaniu liczbami w postaci cyfr arabskich. Jest to rezultat sukcesywnego przyswajania zależności zachodzących między reprezentacją analogową, werbalną i wzrokowo-symboliczną. Na tym etapie edukacji dzieci dokonują obliczeń pisemnych, poznają pojęcie parzystości, rozumieją bardziej złożone fakty i operacje arytmetyczne ${ }^{23}$. Obszarem odpowiadającym za tę reprezentację liczb są struktury potyliczne i skroniowe w obu półkulach mózgu ${ }^{24}$.

Obok reprezentacji wzrokowo-symbolicznej kształtuje się jeszcze przestrzenna reprezentacja liczb związana $\mathrm{z}$ tak zwaną mentalną osią liczbową (ang. Mental Number Line, MNL) ${ }^{25}$. Organizacja liczb na MNL przebiega w sposób rosnący: liczby o niskiej wartości umieszczone są po stronie lewej MNL, zaś o wyższej - po stronie prawej. Istnienie MNL manifestuje się w umiejętności wykonywania obliczeń w przybliżeniu, myśleniu arytmetycznym, szacowaniu pozycji liczby na osi, porządkowaniu liczb ${ }^{26}$. Neuronalne podstawy przestrzennej reprezentacji liczb zlokalizowano $\mathrm{w}$ płatach ciemieniowych ${ }^{27}$.

Warto zaznaczyć, że wraz z kształtowaniem kolejnych typów umysłowych reprezentacji liczb wzrasta pojemność pamięci roboczej, co jest uzasadnione wzrostem złożoności rozwiązywanych problemów arytmetycznych ${ }^{28}$.

\section{Deficyty poznawcze dotyczące umiejętności matematycznych. Dyskalkulia}

Dyskalkulia jest traktowana jako zaburzenie dotyczące umiejętności matematycznych, jednakże faktycznie obejmuje bardzo szeroki zakres deficytów funkcji poznawczych, zdolności i strategii, na które mają wpływ czynniki biologiczne,

${ }^{21}$ M.G. von Aster, R.S. Shalev, dz. cyt.

22 Tamże.

${ }^{23}$ B. Butterworth, dz. cyt.; M.G. von Aster, R.S. Shalev, dz. cyt.

${ }^{24}$ S. Dehaene, N. Tzourio, V. Frak, L. Reynaud, L. Cohen, J. Mehler, B. Mazoyer, Cerebral activations during number multiplication and comparison: A PET study, „Neuropsychologia” 1996, t. 34, nr 11, s. 1097-1106.

${ }^{25}$ S. Dehaene, Varieties of numerical abilities, „Cognition” 1992, t. 44, s. 1-42; F. Restle, Speed of adding and comparing numbers, „Journal of Experimental Psychology” 1970, t. 83, s. 274-278.

${ }^{26}$ M.G. von Aster, R.S. Shalev, dz. cyt.

27 S. Dehaene, M. Piazza, P. Pinel, L. Cohen, Three parietal circuits for number processing, „Cognitive Neuropsychology" 2003, t. 20, s. 487-506.

${ }^{28}$ M.G. von Aster, R.S. Shalev, dz. cyt. 
środowiskowe, kognitywne i społeczne ${ }^{29}$. Jest to przyczyną ogromnej złożoności deficytu oraz problemu z jego jednoznacznym zdefiniowaniem i wyizolowaniem konkretnej przyczyny. Niejednoznaczność definicji skutkuje z kolei brakiem uniwersalnych kryteriów klasyfikacji dyskalkulii, co sprawia, że granica pomiędzy tym zaburzeniem a innymi formami trudności w zakresie umiejętności matematycznych jest rozmyta. Szacuje się, że dyskalkulia dotyka około 3-6\% populacji30, choć należy pamiętać, że ze względu na niejednoznaczność objawów, trudności w definicji oraz współwystępowanie dyskalkulii $\mathrm{z}$ innymi deficytami ${ }^{31}$, wielu dyskalkulików nie jest zdiagnozowanych lub są oni diagnozowani nieprawidłowo. Neuronalne korelaty tego deficytu to nieprawidłowości w obrębie struktur kluczowych dla operowania przestrzennymi reprezentacjami liczb ${ }^{32}$ i są to zarówno atypowe wzorce struktury, jak i aktywacji sieci ciemieniowo-czołowej odpowiedzialnej za przetwarzanie liczb ${ }^{33}$.

\section{Trudności w okresie wczesnoszkolnym}

Poniżej 6. roku życia dzieci są uczone podstawowych umiejętności matematycznych obejmujących proste obliczenia (zwykle w zakresie od 1 do 10), porządkowanie liczb, określanie względnej wielkości kształtów oraz przeliczanie obiektów ${ }^{34}$. Już na tym etapie u dzieci dyskalkulicznych zauważane są trudności w opanowaniu bazowych umiejętności. Obserwuje się problemy z połączeniem pojęcia liczby z jej symboliczną i ilościową postacią. Pojawiają się przeszkody w rozpoznawaniu liczebności zbioru obiektów, uczeniu się symboli liczb, jak również w wyobrażeniu wartości liczbowych odnoszących się do rzeczywistych przedmiotów ${ }^{35}$. Mają też trudności

${ }_{29}$ M.M.M. Mazzocco, P. Räsänen, Contributions of longitudinal studies to evolving definitions and knowledge of developmental dyscalculia, ,Trends in Neuroscience and Education” 2013, t. 2, nr 2, s. $65-73$.

${ }^{30}$ R.S. Shalev, J. Auerbach, O. Manor, V. Gross-Tsur, Developmental dyscalculia: prevalence and prognosis, „European Child \& Adolescent Psychiatry” 2000, t. 9, nr 2, s. 58-64.

31 K. Kucian, M. von Aster, dz. cyt.

${ }^{32}$ K. Kucian, T. Loenneker, T. Dietrich, M. Dosch, E. Martin, M. von Aster, Impaired neural networks for approximate calculation in dyscalculic children: a functional MRI study, ,Behavioral \& Brain Function” 2006, t. 2, s. 31; C. Mussolin, S. Mejias, M.P. nrl, Symbolic and nonsymbolic number comparison in children with and without dyscalculia, „Cognition” 2010, t. 115, s. 10-25.

${ }^{33}$ N. Molko, A. Cachia, D. Riviere, J.F. Mangin, M. Bruandet, D. Le Bihan, L. Cohen, S. Dehaene, Functional and structural alterations of the intraparietal sulcus in a developmental dyscalculia of genetic origin, „Neuron” 2003, t. 40, s. 847-858.

${ }^{34}$ E. Kikas, K. Peets, A. Palu, J. Afanasjev, The role of individual and contextual factors in the development of maths skills, „Educational Psychology: An International Journal of Experimental Educational Psychology" 2009, t. 29, nr 5, s. 541-560.

${ }^{35}$ L. Cipolotti, B. Butterworth, G. Denes, A Specific deficit for numbers in a case of dense Acalculia, „Brain” 1991, t. 114, nr 6, s. 2619-2637. 
w przeliczaniu obiektów, zwłaszcza powyżej 10 oraz odliczaniu wstecz ${ }^{36}$. Ponadto dzieci z dyskalkulią wykazują się słabszą umiejętnością rozpoznawania, nazywania i przedstawiania kształtów - stąd ich awersja do wszelkich układanek czy puzzli37 ${ }^{37}$.

\section{Trudności w okresie szkolnym}

U dzieci starszych obserwuje się problemy widoczne podczas pisania i czytania, polegające na myleniu i zamianie wizualnie podobnych liczb ${ }^{38}$. Dzieci te nie operują sprawnie słownictwem matematycznym ${ }^{39}$, mają trudności nie tylko ze zrozumieniem i rozróżnieniem symboli operacji, ale i samych liczb ${ }^{40}$. Powszechnie spotykane jest też u nich przestrzenne przekształcanie cyfr, jak i zamiana kolejności cyfr tworzących liczbę ${ }^{41}$. Kolejnym zauważanym u nich problemem jest kłopot $\mathrm{z}$ umieszczaniem cyfr w odpowiedniej kolejności, zgodnej z ich wartością ${ }^{42}$. Trudność sprawia nawet zapamiętanie oraz automatyczne przywoływanie liczb ${ }^{43}$. Dzieci dyskalkuliczne nie tylko operacje arytmetyczne wykonują znacznie gorzej od swoich rówieśników, ale też nie zawsze prawidłowo używają symboli arytmetycznych. Zazwyczaj unikają też gier strategicznych, gdzie wymagana jest zdolność logicznego myślenia ${ }^{44}$. Natomiast jeżeli chodzi o geometrię, dzieci te nie są zdolne do przyswojenia słownictwa niezbędnego do opisu właściwości geometrycznych ${ }^{45}$, co jest przyczyną trudności w postrzeganiu i używaniu terminologii dotyczącej tego rodzaju pojęć, a także werbalnego opisu właściwości figur. Percepcja czasu również nie pozostaje bez zakłócen - występują u nich trudności w rozróżnianiu i identyfikacji konceptów czasowych (godziny, dni, miesiące) ${ }^{46}$.

${ }^{36}$ R.S. Shalev, J. Auerbach, O. Manor, V. Gross-Tsur, dz. cyt.

${ }^{37}$ E. Levenson, D. Tirosh, P. Tsamir, Preschool Geometry Theory, Research, and Practical Perspectives, https://www.sensepublishers.com/media/785-preschool-geometry.pdf.

${ }^{38}$ R.S. Shalev, Developmental Dyscalculia, „Journal of Child Neurology” 2004, t. 19, nr 10, s. $765-771$.

39 K. Landerl, A. Bevan, B. Butterworth, Developmental dyscalculia and basic numerical capacities: a study of 8-9-year-old students, „Cognition” 2004, t. 93, nr 2, s. 99-12.

40 A. Plerou, Dealing With Dyscalculia Over Time. International Conference on Information Communication Technologies in Education (ICICTE), Greece 2014 [?].

${ }^{41}$ A. Ardila, M. Rosselli, Acalculia and Dyscalculia, „Neuropsychology Review” 2002, t. 12, nr 4, s. $179-231$.

${ }^{42}$ A. Plerou, dz. cyt.

${ }^{43}$ R.S. Shalev, dz. cyt.

${ }^{44}$ A. Plerou, dz. cyt.

45 E. Smith, M. de Villiers, A Comparative Study of Two Van Hiele Testing Instruments. Paper presented at the 13th Conference for the Psychology of Mathematics Education (PME-13), Paris 1989.

${ }^{46}$ M. Cappelletti, E.D. Freeman, B.L. Butterworth, Time Processing in Dyscalculia, „Frontiers in Psychology" 2001, t. 2, nr 364. 


\section{Trudności w dorosłości}

Osobom dorosłym, dotkniętym dyskalkulią, problem sprawia skuteczne przyswojenie aksjomatów i twierdzeń, w których wymagana jest percepcja trójwymiarowa ${ }^{47}$. Zmagają się też z trudnościami w rozróżnianiu liczb rzeczywistych, a także w postrzeganiu i wykonywaniu operacji na zmiennych. Rozwiązywanie równań algebraicznych w zaawansowanej matematyce, naukach przyrodniczych, inżynierii, biznesie i finansach również stanowi dla nich wyzwanie ${ }^{48}$. Ponadto nie bez znaczenia pozostają trudności odnoszące się do matematyki, a pojawiające się w codziennym życiu, tj. przeliczanie wartości pieniędzy czy prawidłowe oszacowanie kosztów produktów ${ }^{49}$. Zauważalny jest także słaby zmysł przestrzenny ${ }^{50}$ oraz problem w postrzeganiu i zarządzaniu czasem (tj. nieprawidłowe szacowanie czasu wymaganego do ukończenia zadania, kłopot $\mathrm{z}$ postępowaniem według harmonogramu, przypominanie sobie kolejności zdarzeń przeszłych i przyszłych) ${ }^{51}$.

Warto zauważyć, że dyskalkulia jest zaburzeniem towarzyszącym jednostce całe życie. Trudności w zakresie matematyki dotyczą jedynie bardziej złożonych zagadnień, ale opierają się na umiejętnościach bazowych, zdobywanych i rozwijanych we wczesnych etapach edukacji.

\section{Ucieleśnienie matematyki}

Jeżeli natura naszych ciał ma wpływ na to, w jaki sposób zachodzą procesy poznawcze, to musi również istnieć ucieleśnienie umiejętności matematycznych ${ }^{52}$. Sieć neuronalna umożliwiająca przetwarzanie numeryczne angażuje bowiem rejony mózgu związane z takimi funkcjami kognitywnymi, jak pamięć, uwaga, percepcja, kontrola ruchowa i zdolności wzrokowo-przestrzenne ${ }^{53}$. Wiadomo już też, że człowiek posiada wrodzone podstawy bazowych umiejętności matematycznych

${ }^{47}$ M.A. Yazdani, The Gagne Van Hieles Connection: A Comparative Analysis of Two Theoretical Learning Frameworks, „Journal of Mathematical Sciences \& Mathematics Education” 2008, t. 3, nr 1, s. $58-63$.

${ }^{48}$ L. Fradkin, Teaching algebra and calculus to engineering fresher's via Socratic Dialogue and Eulerian sequencing. Paper presented at the International Conference on Engineering Education ICEE, Gliwice 2010.

49 S. Purohit, S. Margaj, Analysis and Detection of Dyscalculia at Early Age Using Computer Assisted Friendly Tests [CrAFT], „International Journal of Emerging Technology and Advanced Engineering" 2008, t. 2, nr 12, s. 289-295.

50 A. Ardila, M. Rosselli, dz. cyt.

${ }^{51}$ S. Purohit, S. Margaj, dz. cyt.

52 A.M. Glenberg, Embodiment as a unifying perspective for psychology, „Wiley Interdisciplinary Reviews: Cognitive Science" 2010, t. 1, nr 4, s. 586-596.

${ }^{53}$ K. Kucian, M. von Aster, dz. cyt. 
zlokalizowane przede wszystkim - jak wspomniano wcześniej - w strukturach dolnej kory ciemieniowej. Nie wystarcza to jednak, by wytłumaczyć, w jaki sposób powstają skomplikowane teorie matematyczne ${ }^{54}$. Z pomocą przychodzi więc teoria poznania ucieleśnionego, która podkreśla, że zarówno matematyka formalna, jak i abstrakcyjna jest zakorzeniona w doznaniach sensoryczno-motorycznych ${ }^{55}$. Matematyka opiera się na pojęciach abstrakcyjnych, których konceptualizację umożliwiają metafory traktowane przez niektórych jako narzędzia myślenia, działania i percepcji $i^{56}$.

\section{Związek matematyki z przestrzenią}

Związek liczb z przestrzenią jako pierwsi zauważyli Dehaene, Bossini i Giraux ${ }^{57}$. Przeprowadzili oni badania dotyczące zależności przestrzennej między liczbą i stroną odpowiedzi (którą nazwali efektem SNARC, ang. Spatial-Numerical Association of Response Codes). Zadanie badanych polegało na klasyfikacji prezentowanych liczb jako parzystych lub nieparzystych za pomocą wciśnięcia prawego lub lewego klawisza (zgodnie z instrukcją). Mierzono czas reakcji i zaobserwowano, że badani szybciej reagowali lewą ręką, jeżeli wartości liczbowe były niskie, natomiast prawą - jeżeli wartości były wyższe ${ }^{58}$. Zależność ta wynika stąd, że czas reakcji jest krótszy w przypadku zgodności między stroną reakcji i stroną lokalizacji poznawczej reprezentacji liczby na MNL.

Efekt SNARC znajduje również uzasadnienie na gruncie teorii umysłu ucieleśnionego, a dokładniej teorii metafor rozwijanej przez Lakoffa i Núñeza ${ }^{59}$. Przestrzeń w rozumieniu naturalnym, ale i potocznym jest traktowana jako absolutnie ciągła, podobnie jak linia. Z kolei punkty nie są obiektami, a jedynie lokalizacja$\mathrm{mi}$ - w przestrzeni, na prostej ${ }^{60}$. To dało podstawę do sformułowania metafory, na której bazuje pojęcie osi liczbowej, a zgodnie z którą liczby są punktami na prostej ${ }^{61}$. Kolejne punkty są więc liczbami naturalnymi, natomiast prosta jest osią liczbową, na której każda liczba ma swoje miejsce i są one uporządkowane od strony

${ }^{54}$ M.L. Hohol, Matematyczność ucieleśniona, [w:] Oblicza racjonalności. Wokół myśli Michała Hellera, red. B. Brożek, J. Mączka, W.P. Grygiel, M.L. Hohol, Kraków 2011, s. 143-166.

${ }^{55}$ L. Bazzini, C. Sabena, B. Villa, Meaningful context in mathematical problem solving: a case study. Proceedings of the 3rd International Conference on Science and Mathematics Education, 2009 [?]

${ }^{56}$ G. Lakoff, M. Johnson, Metafory w naszym życiu, tłum. T.P. Krzeszowski, Warszawa 2010.

57 S. Dehaene, S. Bossini, P. Giraux, The Mental Representation of Parity and Number Magnitude, „Journal of Experimental Psychology: General” 1993, t. 122, nr 3, s. 371-396.

58 Tamże.

${ }^{59}$ M.L. Hohol, dz. cyt.

${ }^{60}$ J. Pogonowski, Geneza matematyki wedle kognitywistów, „Investigationes Linguisticae” 2011, nr 23, s. 106-147.

${ }^{61}$ Tamże. 
lewej do prawej - rosnąco. Funkcjonowanie tej metafory umożliwia mapowanie liczb na przestrzeń ${ }^{62}$, a zatem przestrzeń jest niezbędna w szeregowaniu liczb.

Warto zauważyć, że właściwie ukształtowana przestrzenna reprezentacja liczb ma związek z ogólnymi matematycznymi osiągnięciami dzieci ${ }^{63}$. Zatem ważne jest, by wspierać kształtowanie i utrwalanie MNL, ponieważ operowanie mentalną osią liczbową to umiejętność, która pozwala na efektywne radzenie sobie z arytmety$\mathrm{kaq}^{64}$. Dowodów na to dostarczyły między innymi badania Kucian i współpracowników $(2011)^{65}$, którzy sprawdzali skuteczność gry komputerowej polegającej na precyzyjnym wskazaniu pozycji danej liczby - bądź wyniku działania matematycznego - na osi liczbowej, poprzez manipulowanie położeniem rakiety. Po odbyciu treningu $\mathrm{z}$ użyciem tej gry u dzieci zaobserwowano znaczny wzrost dokładności szacowania miejsca liczb na osi, a także poziomu umiejętności arytmetycznych, czyli operowania MNL ${ }^{66}$.

Reasumując, efekt SNARC i organizacja MNL dzięki zachowaniu spójności między przestrzenią zewnętrzną i wewnętrzną ${ }^{67}$ są niejako potwierdzeniem relacji między przetwarzaniem przestrzeni i liczb.

\section{Związek umiejętności matematycznych ze sprawnością motoryczną}

Procesy poznawcze odpowiedzialne za operowanie liczbami są związane z ogólną aktywnością i codziennymi doświadczeniami, takimi jak m.in. zdolność do grupowania obiektów, rozmieszczania ich w przestrzeni i postrzegania ich $\mathrm{w}$ ruchu, orientacja własnego ciała w przestrzeni czy percepcja podstawowych relacji przestrzennych ${ }^{68}$. Jak wskazuje Lakoff i Núñez $(2000)^{69}$, szczególnie istotna dla tworzenia abstrakcyjnych pojęć matematycznych jest sprawność motoryczna i jej programy - rozpoczynanie, zaprzestawanie i wznawianie działań, gotowość

${ }^{62}$ M.L. Hohol, dz. cyt.

${ }^{63}$ U. Fischer, K. Moeller, M. Bientzle, U. Cress, H.C. Nuerk, Sensi-motor spatial training of number magnitude representation, „Psychonomic Bulletin \& Review” 2011, t. 18, nr 1, s. 177-183.

${ }^{64}$ J.L. Booth, R.S. Siegler, Developmental and individual differences in pure numerical estimation, „Developmental Psychology” 2006, t. 41, nr 6, s. 189-201; S. Dehaene, M. Piazza, P. Pinel, L. Cohen, dz. cyt.

${ }^{65}$ K. Kucian, U. Grond, S. Rotzer, B. Henzi, C. Schönmann, F. Plangger, M. Gälli, E. Martin, M. von Aster, Mental number line training in children with developmental dyscalculia, „Neuroimage” 2011, t. 57, s. 782-795.

${ }^{66}$ Tamże.

${ }^{67}$ M.H. Fischer, S. Shaki, Spatial associations in numerical cognition - From single digits to arithmetic, „The Quarterly Journal of Experimental Psychology” 2014, t. 67, nr 8, s. 1461-1483.

${ }^{68}$ M.L. Hohol, dz. cyt.

${ }^{69}$ G. Lakoff, R.E. Núñez, Where Mathematics Comes From. How the Embodied Mind Brings Mathematics into Being, New York 2000. 
do konkretnych ruchów ciała (bądź zaprzestania ich), powtarzanie procesów, wykonywanie celowych ruchów, a także rozpoznawanie osiągnięcia celu i sprawdzanie poprawności zastosowanej procedury. Wobec tego sprawność ruchowa ma istotne znaczenie dla rozwoju umiejętności matematycznych, bowiem zdolności matematyczne rozwijają się dzięki aktywności dziecka w przestrzeni. Sprawność motoryczna umożliwia z kolei aktywną eksplorację - co jest zgodne z teorią ucieleśnionego poznania. Potwierdzają to wyniki badań wskazujące, że dzieci charakteryzujące się wyższą sprawnością motoryczną uzyskują lepsze wyniki w matematyce jeszcze przed rozpoczęciem edukacji przedszkolnej, a także robią większe postępy w nauce matematyki na przestrzeni roku ${ }^{70}$.

Istotnie, sprawność ruchowa jest predyktorem zdolności matematycznych ${ }^{71}$. Pokazali to m.in. Reikerås, Moser i Tønnessen $(2015)^{72}$, sprawdzając relację pomiędzy podstawowymi zdolnościami numerycznymi i sprawnością motoryczną. Obserwacji poddano aż 1093 trzyletnich dzieci. Dwóch badaczy (niezależnie od siebie) przyglądało się każdemu dziecku podczas zabawy i codziennych czynności w środowisku przedszkolnym przez trzy miesiące. Z grupy badanych wybrano 450 dzieci, a następnie tę grupę podzielono na 3 podgrupy charakteryzujące się najniższym (1) i najwyższym (2) poziomem zdolności motorycznych, a także poziomem zbliżonym do średniej całej próby (3, grupa kontrolna). Wyniki były zgodne z wynikami wcześniejszych badań dotyczących dzieci starszych ${ }^{73}$. Potwierdzono, że istnieje dodatnia korelacja między sprawnością motoryczną i umiejętnościami matematycznymi. Skąd ten związek? Otóż uważa się, że sprawność fizyczna jest podstawą dla rozwoju zdolności wzrokowo-przestrzennych. Myślenie przestrzenne wspiera natomiast rozumienie pojęć liczbowych, a wymiar przestrzenny jest niezbędny w szeregowaniu liczb i w liczeniu ${ }^{74}$.

Z kolei Grissmer i współpracownicy ${ }^{75}$ badali funkcje wykonawcze i sprawność motoryczną u dzieci w wieku przedszkolnym (4-5 lat). Ocena sprawności motorycznej obejmowała szereg zadań konstrukcyjnych. Niektóre z nich wymagały od

${ }^{70}$ C.E. Cameron, L.L. Brock, W.B. Murrah, L.H. Bell, S.L. Worzalla, D. Grissmer, F.J. Morrison, Fine motor skills and executive function both contribute to kindergarten achievement, „Child Development" 2012, t. 83, nr 4, s. 1229-1244.

${ }^{71}$ B.N. Veldine, R.M. Golinkoff, K. Hirsh-Pasek, N.S. Newcombe, Spatial skills, their development, and their links to mathematics, „The Society for Research in Child Development” 2017, t. 82, nr 1, s. 7-30.

${ }^{72}$ E. Reikerås, T. Moser, F.E. Tønnessen, dz. cyt.

${ }^{73}$ Tamże.

74 Tamże.

75 B.N. Verdine, C.M. Irwin, R.M. Golinkoff, K. Hirsh-Pasek, Contributions of Executive Function and Spatial Skills to Preschool Mathematics Achievement, „Journal of Experimental Child Psychology" 2014, t. 126, s. 37-51. 
dzieci także orientacji przestrzennej i rozpoznawania kształtów. Wyniki pokazały, że dzieci z wyższym poziomem funkcji wykonawczych i sprawności motorycznej charakteryzują się lepszymi wynikami w zakresie czytania i matematyki. Zatem dzieci w tym wieku, które cechują się wysokim poziomem zdolności motorycznych prawdopodobnie mają większe możliwości w zakresie przetwarzania bardziej złożonych pojęć, w tym cyfr i liter ${ }^{76}$.

O związku matematyki - czy generalnie zdolności poznawczych - z ruchem świadczy też fakt, że dzieci przejawiające deficyty poznawcze, takie jak ADHD czy dysleksja, często charakteryzują się również zaburzeniami funkcji motorycznych. Podobnie u dzieci z deficytami ruchowymi często występują trudności w nauce ${ }^{77}$.

\section{Zdolności matematyczne a gestykulacja}

Wyniki badań wskazują na ścisły związek gestykulacji z mową w komunika$\mathrm{cji}^{78}$. Co więcej, uważa się, że gestykulacja ma wpływ na procesy myślenia i gromadzenia wiedzy ${ }^{79}$. To sprawia, że rola gestykulacji nie ogranicza się do bycia narzędziem w procesie komunikacji, a zaczyna być postrzegana jako fundamentalna w kształtowaniu myślenia ${ }^{80}$.

Myślenie matematyczne obejmuje złożoną interakcję języka i reprezentacji, które odwołują się głównie do doświadczeń i działań cielesnych. Matematyka jest więc, zgodnie z teorią poznania ucieleśnionego, wytworem człowieka i jego cielesnej aktywności w otaczającym świecie ${ }^{81}$. Badania dotyczące roli gestykulacji w procesie nauki wskazują, że angażowanie swojego ciała podczas przyswajania złożonych pojęć usprawnia ich rozumienie i zapamiętywanie ${ }^{82}$. Istotnie - kiedy dzieci dokonują operacji matematycznych, takich jak dodawanie i odejmowanie często używają swoich palców, które służą im jako fizyczna reprezentacja tych abstrakcyjnych idei ${ }^{83}$.

Liczenie na palcach jest użyteczną strategią na wczesnym etapie rozwoju umiejętności matematycznych, co pokazało m.in. badanie podłużne Jordana

${ }^{76}$ C.E. Cameron, L.L. Brock, W.B. Murrah, L.H. Bell, S.L. Worzalla, D. Grissmer, F.J. Morrison, dz. cyt.

77 Tamże.

${ }^{78}$ L. Bazzini, C. Sabena, B. Villa, dz. cyt.

79 S. Goldin-Meadow, M. Wagner Alibali, Gesture's Role in Speaking, Learning, and Creating Language, „Annual Review in Psychology” 2001, t. 64, s. 257-83.

${ }^{80}$ Tamże.

81 Tamże.

${ }^{82}$ D. DeSutter, M. Stieff, Teaching students to think spatially through embodied actions: Design principles for learning environments in science, technology, engineering, and mathematics, „Cognitive Research: Principles and Implications" 2017, t. 2, s. 22.

${ }^{83}$ Tamże. 
i współpracowników ${ }^{84}$. Wzięło w nim udział 217 dzieci, które poddano pomiarom jedenaście razy, począwszy od rozpoczęcia edukacji przedszkolnej, a skończywszy na końcu drugiej klasy. Dzieci, które posługiwały się palcami podczas liczenia, lepiej radziły sobie z rozwiązywaniem problemów matematycznych. Na przestrzeni czasu ich umiejętności matematyczne wzrastały, podczas gdy częstotliwość liczenia na palcach malała ${ }^{85}$. Zatem wydaje się, że w miarę upływu czasu dzieci rozwijają bardziej zaawansowane i skuteczne strategie umożliwiające efektywne radzenie sobie z matematyką, co jest naturalne. Jednakże liczenie na palcach niewątpliwie stanowi istotny element poznania matematycznego na pewnym etapie rozwoju ${ }^{86}$.

Jakie korzyści wynikają z liczenia na palcach? Strategia ta m.in. pozwala na tworzenie wzrokowo-przestrzennej reprezentacji liczb, zrozumienie systemu dziesiętnego liczb czy zasady kardynalności. Umożliwia też odciążenie pamięci roboczej oraz zachowanie stałego porządku podczas wymawiania etykiet liczbowych. W związku z tym liczenie na palcach stanowi kolejny silny argument na rzecz ważnej roli ucieleśnienia w poznaniu matematycznym ${ }^{87}$.

Dowodem ucieleśnionej matematyki jest też rozwijający się w kulturach Zachodu system [sub-base 5 system] będący konsekwencją liczenia na palcach ${ }^{88}$. Jego stosowanie przejawia się tym, że liczby większe od 5 są przedstawiane na palcach jako 5 palców jednej dłoni i określona liczba palców drugiej dłoni.

\section{Efektywność czuciowo-ruchowego treningu zdolności matematycznych}

Jedną z podstawowych kompetencji numerycznych, która ma szczególne znaczenie dla rozwoju umiejętności arytmetycznych, jest przetwarzanie przestrzennej reprezentacji wielkości liczbowej ${ }^{89}$. Dzieci, u których MNL jest lepiej ukształtowana, osiągają wyższe wyniki w zadaniach matematycznych, a także z większą łatwością uczą się rozwiązywać nowe problemy arytmetyczne ${ }^{90}$. Co więcej, zadania $\mathrm{z}$ osią liczbową są z powodzeniem wykorzystywane w działaniach zmierzających

${ }^{84}$ N.C. Jordan, D. Kaplan, C. Ramineni, M.N. Locuniak, Development of number combination skill in the early school years: when do fingers help?, „Developmental Science” 2008, t. 11, nr 5, s. 662-668 .

85 Tamże.

${ }^{86}$ K. Cipora, M. Szczygieł, M. Hohol, Palce, które liczą: znaczenie liczenia na palcach dla poznania matematycznego u człowieka dorostego, „Psychologia - Etologia - Genetyka” 2014, nr 30, s. 59-73.

87 Tamże.

${ }^{88}$ F. Domahs, K. Moeller, S. Huber, K. Willmes, H.C. Nuerk, Embodied numerosity: Implicit han$d$-based representations influence symbolic number processing across cultures, „Cognition” 2010, t. 16, s. 251-266.

${ }^{89}$ U. Fischer, K. Moeller, M. Bientzle, U. Cress, H.C. Nuerk, dz. cyt.

${ }^{90}$ J.L. Booth, R.S. Siegler, dz. cyt. 
do niwelowania trudności występujących w dyskalkuliii ${ }^{91}$. Dlatego treningi matematyczne często koncentrują się właśnie na wzmacnianiu mentalnej reprezentacji osi liczbowej, ponieważ zapewnia to generalną poprawę w zakresie umiejętności matematycznych ${ }^{92}$.

Związek pomiędzy liczbą i przestrzenią jest moderowany przez doświadczenia cielesne (podobnie jak w przypadku liczenia na palcach), co potwierdza słuszność teorii poznania ucieleśnionego. Ruchowy trening matematyczny angażujący całe ciało prowadzi do silniejszej aktywacji reprezentacji MNL (w porównaniu do treningu niezawierającego ruchowego komponentu) i tym samym do utrwalenia tej reprezentacji. Fischer i współpracownicy ${ }^{93}$ potwierdzili to, porównując efektywność treningu MNL z wykorzystaniem tabletu oraz z użyciem cyfrowej maty tanecznej u dzieci w wieku 5-6 lat. Mata została użyta po to, by rozwinąć u nich powiązanie liczb o niskich wartościach $\mathrm{z}$ lewą stroną przestrzeni, zaś tych o wyższych wartościach - z prawą. Zadaniem dzieci ćwiczących na macie było porównywanie liczb i skakanie w lewo, jeżeli prezentowana liczba była mniejsza niż liczba odniesienia, bądź w prawo w sytuacji odwrotnej. Natomiast grupa kontrolna (ćwicząca na tablecie) tylko zaznaczała na tablecie liczbę o większej wartości. Trening poznawczo-ruchowy przyniósł znacznie lepsze rezultaty. Dzieci uczestniczące w treningu z matą nie tylko były dokładniejsze w późniejszym wyznaczaniu pozycji liczby na osi, ale także ich umiejętność liczenia była lepsza (mimo że nie była ona bezpośrednio trenowana).

W oparciu o dane, które świadczą o istotnej roli zdolności motorycznych i ruchu $\mathrm{w}$ procesie uczenia, sprawdzano również możliwe rezultaty treningu MNL $\mathrm{z}$ użyciem czujnika ruchu Kinect ${ }^{94}$. Tego rodzaju technologie mogą wspierać kinestetyczne uczenie się i jest to taki rodzaj nauki, w której dodatkowo podejmuje się aktywność fizyczną ${ }^{95}$. W badaniu Link i współpracowników zadaniem dzieci było szacowanie pozycji danej liczby (w przedziale $0-100$ ) poprzez chodzenie wzdłuż osi liczbowej umieszczonej na podłodze. Ich ruchy były nagrywane i analizowane z użyciem czujnika Kinect. Grupa kontrolna natomiast wykonywała to samo zadanie na tablecie. Wyniki tych badań wskazują, że trening poznawczo-ruchowy był

${ }^{91}$ U. Fischer, K. Moeller, M. Bientzle, U. Cress, H.C. Nuerk, dz. cyt.

${ }_{92}$ T. Link, K. Moeller, S. Huber, U. Fischer, H.C. Nuerk, Walk the number line - An embodied training of numerical concepts, „Trends in Neuroscience and Education” 2013, t. 2, s. 74-84; T. Dackermann, U. Fischer, H.C. Nuerk, U. Cress, K. Moeller, Applying embodied cognition: from useful interventions and their theoretical underpinnings to practical applications, „ZDM Mathematics Education" 2017, t. 49, s. 545-557.

${ }^{93}$ U. Fischer, K. Moeller, M. Bientzle, U. Cress, H.C. Nuerk, dz. cyt.

94 T. Link, K. Moeller, S. Huber, U. Fischer, H.C. Nuerk, dz. cyt.

${ }^{95}$ H.M.O. Orona, G.S. Maldonado, N.P.S. Martínez, Kinect TEAM: Kinesthetic Learning Applied to Mathematics Using Kinect, „Procedia Computer Science” 2015, t. 75, s. 169-172. 
bardziej efektywny, bowiem dzieci z pierwszej grupy znacznie poprawiły dokładność szacowania miejsca liczb na osi liczbowej, a ponadto zaobserwowano u nich poprawę w zakresie dodawania.

Myślenie przestrzenne polegające na rozumieniu relacji przestrzennych między obiektami i przestrzenią jest czynnikiem wspierającym rozwój zdolności matematycznych ${ }^{96}$. W badaniu Burte i współpracowników ${ }^{97}$ sprawdzano wpływ ruchowego treningu przestrzennego na myślenie przestrzenne i matematyczne. W badaniu wzięli udział uczniowie szkoły podstawowej (3-6 klasa), u których przed treningiem i po nim dokonano oceny poziomu zdolności matematycznych i przestrzennych. Program treningowy o nazwie Think3d! składał się z zajęć origami i tzw. pop-up paper. Zajęcia takie polegają na składaniu i cięciu papieru, co trenuje myślenie 2- i 3-wymiarowe. Badania te wykazały, że uczestnictwo w programie Think3d! usprawniło myślenie przestrzenne. Zaobserwowano, że wszystkie dzieci poprawiły wyniki w rozwiązywaniu matematycznych problemów, ale tylko tych, które dotyczą realnej rzeczywistości (ang. real-world math problems). Dodatkowo u starszych uczestników (5-6 klasa) zauważono też poprawę w zadaniach angażujących wzrokowo-przestrzenne zdolności matematyczne.

Warto dodać, że zaletą takiego treningu zdolności matematycznych jest utrzymywanie motywacji dziecka na wysokim poziomie dzięki rozrywkowemu charakterowi, a przez to dużej atrakcyjności takich działań edukacyjnych.

\section{Podsumowanie - matematyka ucieleśniona}

$\mathrm{W}$ ramach dokonanego tu przeglądu literatury przedstawiono paradygmat umysłu ucieleśnionego, a także ukazano jego związek z matematyką. Wszystko wydaje się tworzyć spójną całość - ucieleśnione poznanie sprawia, że i matematyka ma swoje źródło w czuciowo-ruchowych interakcjach z otaczającą rzeczywistością. Jest tak, ponieważ matematyka składa się z abstrakcyjnych, trudnych do uchwycenia pojęć. Rodzimy się z bazą biologiczną tych szczególnych zdolności (co pokazują badania $\mathrm{z}$ udziałem niemowląt) umożliwiającą rozwój w tym zakresie. Jednak to aktywne oddziaływanie ze światem - za pośrednictwem i z zaangażowaniem naszego ciała - umożliwia efektywny rozwój matematycznych umiejętności.

${ }^{96}$ D. DeSutter, M. Stieff, dz. cyt.

${ }^{97}$ H. Burte, A.L. Gardony, A. Hutton, H.A. Taylor, Think3d!: Improving mathematics learning through embodied spatial training, „Cognitive Research: Principles and Implications” 2017, t. 2, nr 1, s. 38 . 


\section{BIBLIOGRAFIA}

Ardila A., Rosselli M., Acalculia and Dyscalculia, „Neuropsychology Review” 2002 , t. 12 , nr 4.

Bazzini L., Sabena C., Villa B., Meaningful context in mathematical problem solving: a case study, sprawozdanie $\mathrm{z}$ międzynarodowej konferencji naukowej „The 3rd International Conference on Science and Mathematics Education" 2009.

Booth J.L., Siegler R.S., Developmental and individual differences in pure numerical estimation, „Developmental Psychology” 2006, t. 41, nr 6.

Burte H., Gardony A.L., Hutton A., Taylor H.A., Think3d!: Improving mathematics learning through embodied spatial training, „Cognitive Research: Principles and Implications" 2017, t. 2, nr 1.

Butterworth B., The development of arithmetical abilities, „Journal of Child Psychology and Psychiatry" 2005, t. 46, nr 1.

Cameron C.E., Brock L.L., Murrah W.B., Bell L.H., Worzalla S.L., Grissmer D., Morrison F.J., Fine motor skills and executive function both contribute to kindergarten achievement, „Child Development” 2012, t. 83, nr 4.

Cappelletti M., Freeman E.D., Butterworth B.L., Time Processing in Dyscalculia, „Frontiers in Psychology” 2001, t. 2, nr 364.

Cipolotti L., Butterworth B., Denes G., A Specific deficit for numbers in a case of dense Acalculia, „Brain” 1991, t. 114, nr 6.

Cipora K., Szczygieł M., Hohol M., Palce, które liczą: znaczenie liczenia na palcach dla poznania matematycznego u człowieka dorosłego, „Psychologia - Etologia - Genetyka" 2014, nr 30.

Dackermann T., Fischer U., Nuerk H.C., Cress U., Moeller K., Applying embodied cognition: from useful interventions and their theoretical underpinnings to practical applications, „ZDM Mathematics Education” 2017, t. 49.

de Hevia M.D., Spelke E.S., Number-space mapping in human infants, „Psychological Science" 2010, t. 21.

Dehaene S., Bossini S., Giraux P., The Mental Representation of Parity and Number Magnitude, „Journal of Experimental Psychology: General” 1993, t. 122, nr 3.

Dehaene S., Molko N., Cohen L., Wilson A.J., Arithmetic and the brain, „Current Opinion in Neurobiology" 2004, t. 14, nr 2.

Dehaene S., Number sense. How the mind creates mathematics, United States of America 1997.

Dehaene S., Piazza M., Pinel P., Cohen L., Three parietal circuits for number processing, „Cognitive Neuropsychology” 2003, t. 20. 
Dehaene S., Tzourio N., Frak V., Reynaud L., Cohen L., Mehler J., Mazoyer B., Cerebral activations during number multiplication and comparison: A PET study, „Neuropsychologia” 1996, t. 34, nr 11.

Dehaene S., Varieties of numerical abilities, „Cognition” 1992, t. 44.

Derra A., Język i jego problematyczne właściwości w teorii nrma Chomsky'ego, [w:] Modularność umysłu, red. Sz. Wróbel, Poznań-Kalisz 2007.

DeSutter D., Stieff M., Teaching students to think spatially through embodied actions: Design principles for learning environments in science, technology, engineering, and mathematics, „Cognitive Research: Principles and Implications" 2017, t. 2.

Domahs F., Moeller K., Huber S., Willmes K., Nuerk H.C., Embodied numerosity: Implicit hand-based representations influence symbolic number processing across cultures, „Cognition” 2010, t. 16.

Fischer M.H., Shaki S., Spatial associations in numerical cognition - From single digits to arithmetic, "The Quarterly Journal of Experimental Psychology” 2014, t. 67, nr 8.

Fischer U., Moeller K., Bientzle M., Cress U., Nuerk H.C., Sensi-motor spatial training of number magnitude representation, „Psychonomic Bulletin \& Review" 2011, t. 18, nr 1.

Fradkin L., Teaching algebra and calculus to engineering fresher's via Socratic Dialogue and Eulerian sequencing, sprawozdanie z międzynarodowej konferencji naukowej „International Conference on Engineering Education ICEE", Gliwice, 18-22 lipca 2010 r.

Glenberg A.M., Embodiment as a unifying perspective for psychology, „Wiley Interdisciplinary Reviews: Cognitive Science" 2010, t. 1, nr 4.

Goldin-Meadow S., Wagner Alibali M., Gesture's Role in Speaking, Learning, and Creating Language, „Annual Review in Psychology” 2001, t. 64.

Gonigroszek D., Językoznawstwo kognitywne: „ucieleśniony” umyst i znaczenie. „Językoznawstwo" 2011, nr 5(1).

Held R., Hein A., Movement-produced stimulation in the development of visually guided behavior, „Journal of Comparative and Physiological Psychology" 1963 , t. 56, nr 5.

Hohol M.L., Matematyczność ucieleśniona, [w:] Oblicza racjonalności. Wokół myśli Michała Hellera, red. B. Brożek, J. Mączka, W.P. Grygiel, M.L. Hohol, Kraków 2011.

Hubbard E.M., Piazza M., Pinel P., Dehaene S., Interactions between number and space in parietal cortex, „Nature Review Neuroscience” 2005, t. 6. 
Jordan N.C., Kaplan D., Ramineni C., Locuniak M.N., Development of number combination skill in the early school years: when do fingers help?, „Developmental Science" 2008, t. 11, nr 5.

Kiereś H., Filozofia współczesna, [w:] U źródeł tożsamości kultury europejskiej, red. T. Rakowski, Lublin 1994.

Kikas E., Peets K., Palu A., Afanasjev J., The role of individual and contextual factors in the development of maths skills, „Educational Psychology: An International Journal of Experimental Educational Psychology" 2009, t. 29, nr 5.

Kucian K., Grond U., Rotzer S., Henzi B., Schönmann C., Plangger F., Gälli M., Martin E., von Aster M., Mental number line training in children with developmental dyscalculia, „Neuroimage” 2011, t. 57.

Kucian K., Loenneker T., Dietrich T., Dosch M., Martin E., von Aster M., Impaired neural networks for approximate calculation in dyscalculic children: a functional MRI study, „Behavioral \& Brain Function” 2006, t. 2.

Kucian K., von Aster M., Developmental dyscalculia, „Eur J Pediatr” 2015, t. 174, nr 1.

Lakoff G., Johnson M., Metafory w naszym życiu, tłum. T.P. Krzeszowski, Warszawa 2010.

Lakoff G., Núñez R.E., Where Mathematics Comes From. How the Embodied Mind Brings Mathematics into Being, New York 2000.

Landerl K., Bevan A., Butterworth B., Developmental dyscalculia and basic numerical capacities: a study of 8-9-year-old students, „Cognition” 2004, t. 93, nr 2.

Levenson E., Tirosh D., Tsamir P., Preschool Geometry Theory, Research, and Practical Perspectives, https://www.sensepublishers.com/media/785-preschool-geometry.pdf [dostęp: 12.03.2017].

Link T., Moeller K., Huber S., Fischer U., Nuerk H.C., Walk the number line - An embodied training of numerical concepts, „Trends in Neuroscience and Education" 2013, t. 2.

Mazzocco M.M.M., Räsänen P., Contributions of longitudinal studies to evolving definitions and knowledge of developmental dyscalculia, „Trends in Neuroscience and Education" 2013, t. 2, nr 2.

Moeller K., Fischer U., Nuerk H.C., Cress U., Computers in mathematics education - Training the mental number line, „Computers in Human Behavior” 2015, t. 48.

Molko N., Cachia A., Riviere D., Mangin J.F., Bruandet M., Le Bihan D., Cohen L., Dehaene S., Functional and structural alterations of the intraparietal sulcus in a developmental dyscalculia of genetic origin, „Neuron” 2003, t. 40. 
Munro J., Dyscalculia: A unifying concept in understanding mathematics learning disabilities, „Australian Journal of Learning Disabilities” 2003, t. 8, nr 4.

Mussolin C., Mejias S., nrl M.P., Symbolic and nonsymbolic number comparison in children with and without dyscalculia, „Cognition” 2010, t. 115.

Orona H.M.O., Maldonado G.S., Martínez N.P.S., Kinect TEAM: Kinesthetic Learning Applied to Mathematics Using Kinect, „Procedia Computer Science" 2015, t. 75.

Patro K., Nuerk H.C., Cress U., Haman M., How number-space relationships are assessed before formal schooling: A taxonomy proposal, „Frontiers in Psychology" 2014, t. 5, nr 419.

Plerou A., Dealing With Dyscalculia Over Time, Sprawozdanie z międzynarodowej konferencji naukowej „International Conference on Information Communication Technologies in Education (ICICTE)", Greece 2014.

Pogonowski J., Geneza matematyki wedle kognitywistów, „Investigationes Linguisticae" 2011, nr 23.

Pokropski M., Ciało. Od fenomenologii do kognitywistyki, „Przegląd Filozoficzno-Literacki" 2011, nr 4(32).

Purohit S., Margaj S., Analysis and Detection of Dyscalculia at Early Age Using Computer Assisted Friendly Tests [CrAFT], „International Journal of Emerging Technology and Advanced Engineering" 2008, t. 2, nr 12.

Reikerås E., Moser T., Tønnessen F.E., Mathematical skills and motor life skills in toddlers: do differences in mathematical skills reflect differences in motor skills? „European Early Childhood Education Research Journal” 2015, t. 25, nr 1 .

Restle F., Speed of adding and comparing numbers, „Journal of Experimental Psychology" 1970, t. 83.

Rizzolatti G., Fogassi L., Gallese V., Mirrors In The Mind, „Scientific American” 2006.

Shalev R.S., Auerbach J., Manor O., Gross-Tsur V., Developmental dyscalculia: prevalence and prognosis, „European Child \& Adolescent Psychiatry” 2000 , t. 9 , nr 2.

Shalev R.S., Developmental Dyscalculia, „Journal of Child Neurology” 2004, t. 19, nr 10.

Smith E., de Villiers M., A Comparative Study of Two Van Hiele Testing Instruments, Sprawozdanie z międzynarodowej konferencji naukowej „The 13th Conference for the Psychology of Mathematics Education (PME-13)", Paris 1989. 
Szczygieł M., Cipora K., Hohol M., Liczenie na palcach $w$ ontogenezie i jego znaczenie dla rozwoju kompetencji matematycznych, „Psychologia Rozwojowa" 2015, nr 20.

Tatarkiewicz W., Historia filozofii, t. II, Filozofia nowożytna do roku 1830, Warszawa 2018.

Tran C., Smith B., Buschkuehl M., Support of mathematical thinking through embodied cognition: nrdigital and digital approaches, „Cognitive Research: Principles and Implications" 2017, t. 2.

Trybulec B., Fenomenologia a kognitywistyka - dwie metody analizy podmiotu poznania. Perspektywa wspótpracy i problemy, „Filozofia i nauka. Studia filozoficzne i interdyscyplinarne" 2015, t. 3.

Trzópek J., Na tropach podmiotu. Między filozoficznym a empirycznym ujęciem podmiotowości, Kraków 2013.

Veldine B.N., Golinkoff R.M., Hirsh-Pasek K., Newcombe N.S., Spatial skills, their development, and their links to mathematics, „The Society for Research in Child Development" 2017, t. 82, nr 1.

Verdine B.N., Irwin C.M., Golinkoff R.M., Hirsh-Pasek K., Contributions of Executive Function and Spatial Skills to Preschool Mathematics Achievement, „Journal of Experimental Child Psychology” 2014, t. 126.

von Aster M.G., Shalev R.S., Number development and developmental dyscalculia, „Developmental Medicine \& Child Neurology” 2007, t. 49, nr 11.

Wilson M., Six views of embodied cognition, „Psychonomic Bulletin\&Review” 2002 , t. 9 , nr 4.

Yazdani M.A., The Gagne Van Hieles Connection: A Comparative Analysis of Two Theoretical Learning Frameworks, „Journal of Mathematical Sciences \& Mathematics Education" 2008, t. 3, nr 1. 